\title{
MISCELÁNEA \\ LA ENCOMIENDA DEL CAPITÁN CONTRERAS
}

En estos últimos veinte años ha surgido un nuevo interés por la figura del capitán Alonso de Contreras, Caballero de Malta, uno de los personajes más interesantes y curiosos del siglo xvir español. La Vida, nacimiento, padres y crianza del capitán Alonso de Contreras... escrito por él mismo, compuesta en los años I63o, continuada en I633 y terminada en fecha más tardía, se imprimió por vez primera ell I900, publicada por Serrano y Sanz, en el Boletin de la Real Academia de la Historia. A los pocos años había otras ediciones españolas y traducciones al francés, alemán e inglés. Por causas no fáciles de comprender, pronto disminuyó el interés del público español por este libro y no salió ninguna edición entre I9I2 y I943, fecha esta última de la publicación por la Revista de Occidente de una edición con prólogo de Ortega y Gasset. In rg65 la Vida se incluyó en el tomo XC de la $B A E$ (Autobiografias de soldados. Siglo XVII; ed. J. M. de Cossío). Durante el año de I965 apareció la preciosa edición ilustrada de Manuel Criado de Val (Taurus, Madrid), quien, acudiendo al manuscrito original, que se encuentra en la Academia de la Historia, corrigió el gran número de errores y omisiones de las versiones precedentes. En I967 se publicó la edición de Fernando Reigosa (Alianza Editorial, Madrid), también a base del original.

A pesar del nuevo interés en torno a la figura del capitán Contreras, sabemos poco de él, fuera de lo contado en sus memorias, que a veces son vagas o imprecisas y que terminan en una frase partida, por pérdida de los folios finales. Aunque sus últimos dias y muerte han sido objeto de varias conjeturas, nadie sabe de seguro lo que le pasó a Contreras después de haber escrito su biografía (hacia 1633). Es evidente que si queremos seguir la pista de Contreras después de haber terminado su autobiografía, o si queremos comprobar los datos que él nos da en su misma obra, hay que acudir a los archivos y a otras fuentes fidedignas.

Su autobiografía nos dice que Contreras, durante el año de I6I7, fue recibido en Malta como Iir. Sirviente de Armas de la Orden de San 
Juan de Jerusalén, wen el Priorato de Castilla, sin tener obligación de hacer pruebas necesarias para ellon, y que fue armado caballero, otra vez en Malta, en el año I630. Por consiguiente, una de las fuentes más lógicas para seguir la pista del Capitán es el archivo de la Orden, sea en España, sea en Malta.

Actualmente, el archivo de los Caballeros de Malta en España se encuentra en Madrid, en el Archivo Histórico Nacional, y se divide en dos secciones: a) expedientes o pruebas de nobleza, y b) documentos generales, que reúne todo lo relativo a las encomiendas y a otros asuntos de la Orden.

La sección de expedientes - a pesar de los catálogos- no contiene nada relativo a Contreras, ya que, por una parte, se armó caballero en Malta, no en España, y, por otra, no tuvo que presentar las pruebas de limpieza de sangre, etc., generalmente exigidas a los caballeros.

En la sección de documentos generales se encuentran legajos de más interés y utilidad. Contreras nos cuenta que se le concedió en el año de I663 la encomienda de "San Juan Puente de Orbin, y, consultando la lista de encomiendas de la Orden de Malta en Castilla y León, se comprueba que la villa del Hospital de Puente de Orbigo, a treinta kilómetros de León, era propiedad de los Caballeros de San Juan de Jerusalén y que en el año de $I 640$ había visita general a tal villa. A continuación transcribimos un folio del informe de los caballeros visitadores, que se encuentra en el A. H. N., Sección de Ordenes Militares, San Juan de Jerusalén, segunda serie, legajo 384 , núm. 8 , folio 4 .

Bisita general echa del priorato y encomienda del Capitan Contreras.

En la villa del hospital de puente de Orbigo, a veinte dias del mes de abrill de mill y seiscientos y cuarenta años, los señores don Juan de Cuniga y Contreras, Recibador de la Relixion de San Juan, Comendador de las Encomiendas de Ciudad Rodrigo, Benabente y Rubiales, y el Licençiado F. Francisco Carrasco, Conbentual de Malta, Prior y Bicario de la Villa y Encomienda de Banba, bisitadores xenerales de diclua Relixion ell el partido de Castilla y Ireon por su señoria don Alfonso Iclcastillo y Samano, Bailio de Lora, Lugarthenieute de Gran Prior, del Conscjo de Guerra de Su Magestad, ya abiendo llegado a esta diclia villa, oy, dicho dia, entre las once $y$ doce del mediodía, ha acer bista xeneral en toda esta cncomienda, y abiendo visto que el priorato e iglesia parroquial de San Juan esta debidida y esta echa encomienda del Priorado de Castilla 
para el estado de Fr. Sirbientes y Frailes Capellanes y que al presente es comendador della el Capitán Alonso de Contreras y que el susodicho esta ausente en las Indins y tiene por tiniente e para serbir la iglesia a el Liçençiado Francisco Riesco, presbiter; $y$, despues de aver entimado su courision, antecede don Luis Cansino de Mendoça, Comendador de la encomienda de Puente Dorbigo, que obedeció con el rrespeto debido, de la cual se sacó un traslado para poner por cabeça de bisita de las dos enconiendas, el cual da por cabeça desta bisita que se hace de la encomienda del dicho Pedro de Conrreal ${ }^{1}$. y para saver los bienes y haçienda que dicha encomienda tienc. Los dichos Señores Visitadores, por ante mi, Baltasar Negro, notario publico y apostolico y nonbrado para estas visitas, mandaron que se notifique al diclıo Licenciado Françisco Riesco, teniente de dicho priorato y encomienda que exsiba $\left[\mathrm{v}^{\circ}\right]$ ante sus mercedes un memorial xurado y firmado de su nombre de los vienes $y$ açienda que tiene la dicha encomienda y priorato $y$ con que obligaciones para lo visitar $y$ ver le que modo esta, para le mediar lo que mas conbenga, lo qual cumpla luego, pena de excomunión, y ansi lo mandaron $y$ firmaron.

\section{Ir. don Juan de Cuniga \\ Fr. Francisco Carrazco}

Para servir,

Baltasar Negro, notario.*

Los folios que siguen están dedicados a un inventario de los bienes de la encomienda de Contreras y de la de Cansino de Mendoza, números 5, 6, I2 y I3, llevando más o menos los mismos datos sobre el Capitán.

Este informe ilumina, en aspectos importantes, problemas en torno a la vida de Contreras y a su biografía después de haber terminado sus "Memorias". Fija su encomienda como sólo una parte de la de Hospital de Orbigo (escena del Paso Honroso de Suero de Quiñones). Extraña un poco que Contreras, habiendo subido del estado de Fr. Sirviente de Armas al de Caballero, recibiera una encomienda generalmente reservada para Frailes Sirvientes o Capellanes, pero, vista la escasez de encomiendas en Castilla, es fácil que, faltando otra mejor, recibiera el

1 De dificil lectura y nada claro. Parece que el copista ha borrado y escrito otras letras sobre las ya copiadas. Pedro es corrección, y Conrreal no es nada seguro; es posiblemente Contreras, con una.s alta. 
Caballero Contreras esta pequeña recompensa "en consideración de los servicios".

En segundo lugar, y mucho más importante, el informe nos aporta datos para mejor evaluar las varias teorias propuestas en torno a los últimos días y muerte de Contreras. Descarta por completo una de las conjeturas de Serrano y Sanz, quien sugirió que posiblemente podamos fijar la muerte de Contreras o el 29 de julio de 1637 o el 29 de diciembre de 1653 , basándose en las partidas de defunción de dos personas del mismo nombre $\mathrm{y}$ apellido que nuestro Capitán, enterrados de limosna en Madrid, en la parroquia de San Sebastián. La fecha de la visita aquí transcrita prueba que el de 1637 no era nuestro Contreras, porque éste, a lo menos en la opinión de los Caballeros de la Orden de Malta, vivía aún y estaba en Indias. El segundo dato presentado por Serrano tampoco me parece muy probable no sólo por su fecha tardía, sino también porque Contreras poseía las rentas de la encomienda $y$, aún sin recursos propios, tenía muchos amigos que no le dejarían enterrar de limosna.

Este informe nos indica que debenos seguir la pista de Contreras no sólo en Europa, sino también en Indias, en donde había estado en otra ocasión, ya que es evidente que viajó all entre los años I633 y I640, o como soldado del rey o como aventurero.

Para concluir, este informe nos obliga a reexaminar el problema planteado por las últimas páginas del manuscrito, escritas en fecha iudeterminada y por mano distinta a la de Contreras. Según estos últimos folios, Contreras vino a Madrid en el año 1633 y se alojó «en casa del secretario Juan Ruiz de Contreras, padre de don Fernando, el que hoy está en las alturas". Dou Fernando Ruiz de Contreras fue nombrado Consejero de Indias el 5 de marzo de 1640 , y uen las alturas" parece referirse a su nuevo cargo. Si Contreras estaba en Indias a principios de I640, ¿debemos colegir de esta alusión a F. Ruiz de Contreras que el Capitán volvió a la metrópoli y continuó sus memorias en fecha posterior? Yo creo que sí.

ERIC W. NAYLOR 